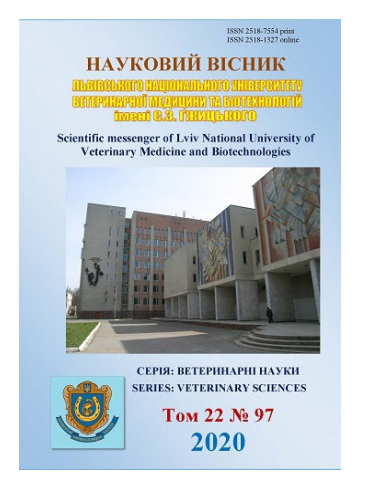

\author{
Науковий вісник Дьвівського національного університету \\ ветеринарної медицини та біотехнологій імені С.3. Гжицького. \\ Серія: Ветеринарні науки \\ Scientific Messenger of Lviv National University \\ of Veterinary Medicine and Biotechnologies. \\ Series: Veterinary sciences
}

ISSN 2518-7554 print ISSN 2518-1327 online doi: $10.32718 /$ nvlvet9720

https://nvlvet.com.ua/index.php/journal

UDC 636.598.9:616.995.132(477.53)

\title{
Distribution of trichostrongylosis of geese on the territory of Poltava region
}

\author{
V. O. Yevstafieva, Y. S. Starodub \\ Poltava State Agrarian Academy, Poltava, Ukraine
}

Article info

Received 11.02.2020

Received in revised form 12.03 .2020

Accepted 13.03.2020

Poltava State Agrarian Academy, Skovorody Str., 1/3, Poltava, 36003, Ukraine.

Tel.: $+38-050-183-78-78$

E-mail:evstva@ukr.net
Yevstafieva, V. O., \& Starodub, Y. S. (2020). Distribution of trichostrongylosis of geese on the territory of Poltava region. Scientific Messenger of Lviv National University of Veterinary Medicine and Biotechnologies. Series: Veterinary sciences, 22(97), 125-129. doi: 10.32718/nvlvet9720

Successful development of poultry farming can be achieved not only as a result of the creation of highly productive new breeds of geese, the improvement of diets for nutrients, but also in the conditions of stable epizootic well-being of infectious and invasive diseases. Parasitic diseases of domestic waterfowl account for a large proportion of other diseases and cause significant damage to geese farming. Among helminthiases of geese, infections caused by nematodes parasitizing in the gastrointestinal tract of birds, in particular Trichostrongylus tenuis, are quite common. The aim of this study was to study the distribution of trichostrongylosis among populations of domestic geese in the territory of Poltava region, Ukraine (Velyka Bahachka, Hlobyne, Hrebinka, Zinkiv, Karlivka, Poltava, Myrhorod, Shyshaky districts). The conducted scatoscopical studies showed that the average extensity and intensity of trichostrongylosic infestation was respectively $22.9 \%$ and $89.7 \pm 8.2$ eggs per $1 \mathrm{~g}$ of poultry feces. Invasiveness in the region studied ranged from 17.2 to $26.7 \%$ and from 20 to 380 eggs per $1 \mathrm{~g}$ of feces. At the same time, it was found out that the degree of affliction of domestic geese by the agent of trichostrongylosis in farms with different capacity and technology of keeping was significantly different. In individual farms and farms, the extensity and intensity of the invasion of geese is higher $(24.4 \%$ and $97.7 \pm 10.7$ eggs per $1 \mathrm{~g}$ of feces) than in the specialized geese farms (16.1\% and $70.3 \pm 15.1$ eggs in $1 \mathrm{~g}$ of feces). It has been found that goose trichostrongylosis is more frequently present in the mixinvasions of the digestive canal of the bird along with protosooses and nematodoses. Extensity of mixinvasions reaches $18.1 \%$, which is $78.9 \%$ of the total number of patients at geese trichostrongylosis. Extensity of trichostrongylosic mono-invasion was $4.8 \%(21.1 \%$ of the total invasion of T. tenuis birds). The results of the conducted studies lead to a further, deeper study of the issues of epizootic features of trichostrongylosis of geese, taking into account the seasonal and age dynamics of invasion, as well as the effectiveness of therapeutic and preventive measures.

Key words: geese, trichostrongylosis, distribution, indicators of invasiveness, scatoscopical diagnosis.

\section{Поширення трихостронгільозу гусей на території Полтавської області}

\author{
В. О. Євстаф’єва, Є. С. Стародуб
}

Полтавська державна аграрна академія, м. Полтава, Україна

\footnotetext{
Успішний розвиток птахівництва може здійснюватися не тільки внаслідок створення високопродуктивних нових порід гусей, вдосконалення раціонів за поживними речовинами, а також за умов стійкого епізоотичного благополуччя з інфекційних та інвазійних хвороб. Паразитарні хвороби домашньої водоплавної птиці займають значну частку серед інших захворювань $і$ завдають значних збитків гусівництву. Серед гельмінтозів гусей досить поширеними є інвазї, спричинені нематодами, ияо паразитують у илункового-кишковому тракті птиці, зокрема Trichostrongylus tenuis. Метою роботи було вивчити особливості розповсюдження трихостронгільозу серед популяції домашніх гусей на території Полтавської області, Україна (Великобагачанський, Глобинський, Гребінківський, Зіньківський, Карлівський, Полтавський, Миргородський, Шишацький райони). Проведеними копроовоскопічними дослідженнями встановлено, щчо середня екстенсивність та інтенсивність трихостронгільозної інвазії становила відповідно 22,9\% та 89,7 + 8,2 яєць у 1 г посліду птиці. Показники інвазованості в умовах досліджуваного регіону коливалися від 17,2 до 26,7 \% та від 20 до 380 яєць у 1 г посліду. Водночас з'ясовано, щуо ступінь ураженості домашніх гусей збудником трихостронгі-
} 
льозу у господарствах з різною потужністю та технологією утримання значно відрізнялася. В особистих селянських та фермерських господарствах екстенсивність і інтенсивність інвазї гусей є вищою (24,4 \% та 97,7 1 10,7 яєць у 1 г посліду), ніж у спеціалізованих гусегосподарствах (16,1\% та 70,3 $\pm 15,1$ яєиь у 1 г посліду). Виявлено, шчо трихостронгільоз гусей частіше перебігає у складі мікстінвазій травного каналу птиці разом з протозоозами та нематодозами. Екстенсивність мікстінвазій сягає 18,1\%, щзо становить 78,9\% від загальної кількості хворих на трихостронгільоз гусей. Екстенсивність трихостронгільозної моноінвазії становила 4,8\% (21,1\% від загальної кількості інвазованої Т. тепиіs птиці). Отримані результати проведених досліджень зумовлюють подальше, більш глибоке вивчення питань щуодо епізоотологічних особливостей трихостронгільозу гусей з урахуванням сезонної та вікової динаміки інвазії, а також ефективності лікувально-профілактичних заходів.

Ключові слова: гуси, трихостронгільоз, поширення, показники інвазованості, копроовоскопічна діагностика.

\section{Вступ}

В останні роки в Україні спостерігається тенденція до відродження однієї з традиційних галузей птахівництва - гусівництва, яке займає у виробництві м'яса та перо-пухової сировини одне 3 першорядних значень. Здатність гусей високоякісно та у великих кількостях перетравлювати рослинну клітковину ставить їх на перше місце серед інших видів домашньої птиці (Romanov, 1999; Katerynych et al., 2006; Ruban et al., 2016; Boz et al., 2017).

Успішний розвиток птахівництва може здійснюватися не тільки внаслідок створення високопродуктивних нових порід гусей, вдосконалення раціонів за поживними речовинами, а також за умов стійкого епізоотичного благополуччя щодо інфекційних та інвазійних хвороб (Elmberg et al., 2017; Konell et al., 2019). Паразитарні хвороби домашньої водоплавної птиці займають значну частку серед інших захворювань і завдають значних збитків гусівництву. Серед гельмінтозів гусей досить поширеними $є$ інвазіі, спричинені нематодами, що паразитують у шлункового-кишковому тракті птиці, до яких належить і збудник трихостронгільозу (Enigk \& Dey-Hazra, 1971; Shutler et al., 2012; Kornaś et al., 2015; Hamadani et al., 2017).

Епізоотологічні особливості трихостронгільозу найбільш повно вивчено у диких птахів, причому дана інвазія поширена на території всієї Свропи, Азії, Північної Америки, Африці, Австралії, Новій Гвінеї, Новій Зеландії, де показники екстенсивності інвазії можуть сягати 100,0\%, а інтенсивності інвазії - до 2471 екз. нематод на птицю. Trichostrongylus tenuis, переважно, виділено у Anseriformes (гусеподібних), Galliformes (куроподібних), Gruiformes (журавлеподібних) та Otidiformes (дрофіних) (Delahay \& Moss, 1996; Hudson et al., 1992; Webster et al., 2007; Bhat et al., 2014). Більшість наукових праць присвячено дослідженню паразитування T. tenuis у куріпок, так як збудник дестабілізуюче впливає на динаміку їх чисельності, призводячи до зниження популяції птиці. Причому екстенсивність інвазії у куріпок сягає 90,0 \%, а інтенсивність інвазії - до 30000 екз. нематод (Shaw \& Moss, 1989; Newborn \& Foster, 2002; Seivwright et al., 2004).

В Україні питаннями поширення трихостронгільозу серед домашньої птиці науковці займалися фраг- ментарно, описуючи збудника цієї інвазії, як складову загальної гельмінтофауни водоплавної птиці. Так за результатами вивчення поширення гельмінтозів та протозоозів сільськогосподарської птиці регіону Дніпропетровщини було встановлено, що у домашніх гусей паразитує п’ять видів гельмінтів: капілярії, амідостоми, гангулетераки, дрепанідотенії та трихостронгілюси, де ЕI T. tenuis сягала 100 \%. Разом 3 тим, качки були уражені трихостронгілюсами за ЕI $48 \%$ (Marshalkina et al., 2012). В зв'язку з цим, актуальним $\epsilon$ дослідження поширення трихостронгільозу гусей на території окремих регіонів України.

Метою роботи було вивчити особливості розповсюдження трихостронгільозу серед популяції домашніх гусей на території Полтавської області (Україна).

\section{Матеріал і методи досліджень}

Роботу виконували упродовж 2018-2020 рр. на базі лабораторії кафедри паразитології та ветеринарносанітарної експертизи Полтавської державної аграрної академіі та в умовах 4 спеціалізованих гусегосподарств та 129 фермерських і одноосібних селянських господарств Полтавської області (Великобагачанський, Глобинський, Гребінківський, Зіньківський, Карлівський, Полтавський, Миргородський, Шишацький райони).

Гельмінтоовоскопію проб проводили за кількісним методом (Trach, 1992), вираховували кількість яєць у 1 г посліду птиці (ЯГП). Основними показниками ураження гусей нематодами були екстенсивність та інтенсивність інвазії (ЕI та II). Всього досліджено 2271 проб посліду.

Математичний аналіз отриманих даних проводили 3 використанням пакету прикладних програм Microsoft "ЕXCEL". Розраховували середнє арифметичне (M), його похибку (m), максимальні (max) та мінімальні ( $\mathrm{min})$ значення.

\section{Результати та їх обговорення}

Проведеними дослідженнями встановлено, що трихостронгільоз $є$ поширеною нематодозною інвазією в умовах господарств Полтавської області. Середня екстенсивність інвазії становила 22,94 \% за інтенсивності інвазії 89,79 \pm 8,22 ЯГП (табл. 1). 
Таблиця 1

Поширення трихостронгільозної інвазії гусей у господарствах Полтавської області

\begin{tabular}{|c|c|c|c|c|}
\hline Район & $\begin{array}{c}\text { Досліджено } \\
\text { (гол.) }\end{array}$ & $\begin{array}{l}\text { Інвазовано } \\
\text { (гол.) }\end{array}$ & $\begin{array}{c}\text { EI, } \\
\%\end{array}$ & II, ЯГП, M $\pm \mathrm{m}(\min -\max )$ \\
\hline Великобагачанський & 157 & 27 & 17,20 & $\begin{array}{c}69,63 \pm 10,20 \\
(20-220)\end{array}$ \\
\hline Глобинський & 290 & 71 & 24,48 & $\begin{array}{c}81,41 \pm 7,62 \\
\quad(20-300)\end{array}$ \\
\hline Гребінківський & 433 & 115 & 26,56 & $\begin{array}{c}102,61 \pm 6,91 \\
(20-380)\end{array}$ \\
\hline Зіньківський & 390 & 86 & 22,05 & $\begin{array}{c}106,51 \pm 9,45 \\
(20-380)\end{array}$ \\
\hline Карлівський & 192 & 47 & 24,48 & $\begin{array}{c}81,70 \pm 7,57 \\
(20-220)\end{array}$ \\
\hline Миргородський & 256 & 51 & 19,92 & $\begin{array}{c}118,82 \pm 9,82 \\
(20-320)\end{array}$ \\
\hline Полтавський & 396 & 82 & 20,71 & $\begin{array}{c}49,51 \pm 3,31 \\
(20-160)\end{array}$ \\
\hline Шишацький & 157 & 42 & 26,75 & $\begin{array}{c}108,10 \pm 12,23 \\
(20-320)\end{array}$ \\
\hline Всього по області & 2271 & 521 & 22,94 & $\begin{array}{c}89,79 \pm 8,22 \\
(20-380)\end{array}$ \\
\hline
\end{tabular}

Показники екстенсивності інвазії птиці збудником трихостронгільозу в умовах досліджуваного регіону коливалися від 17,2 до 26,7 \%. Так менший відсоток хворих гусей виявляли в господарствах Великобагачанського, Миргородського та Полтавського районів (ЕI - 17,20, 19,92 та 20,71 \% відповідно). Більшу ураженість птиці T. tenuis встановлено у господарствах Зіньківського (ЕI - 22,05 \%), Глобинського, Карлівського $(24,48 \%)$, Гребінківського $(26,56 \%)$ та Шишацького $(26,75 \%)$ районів.

Показники інтенсивності трихостронгільозної інвазії коливалися від 20 до 380 ЯГП. Найбільші показники II виявлено у гусей господарств Гребінківського
$(102,61 \pm 6,91$ ЯГП), $\quad$ Зіньківського $\quad$ (106,51 \pm 9,45 ЯГП), Шишацького $(108,10 \pm 12,23$ ЯГП) та Миргородського (118,82 $\pm 9,82$ ЯГП) районів. У господарствах Полтавського (49,51 \pm 3,31 ЯГП), Великобагачанського $(69,63 \pm 10,20$ ЯГП), Глобинського $(81,41 \pm$ 7,62 ЯГП), Карлівського (81,70 \pm 7,57 ЯГП) районів показники інтенсивності інвазії не перевищували 100 яєць у 1 г посліду.

Водночас з'ясовано, що ступінь ураженості домашніх гусей збудником трихостронгільозу у господарствах 3 різною потужністю значно відрізнялася (табл. 2).

\section{Таблиця 2}

Показники екстенсивності та інтенсивності трихостронгільозної інвазії гусей у господарствах Полтавської області залежно від їх потужності

\begin{tabular}{cccccc}
\hline Господарства & $\begin{array}{c}\text { Потужність } \\
\text { (гол.) }\end{array}$ & $\begin{array}{c}\text { Досліджено } \\
\text { (гол.) }\end{array}$ & $\begin{array}{c}\text { Інвазовано } \\
\text { (гол.) }\end{array}$ & $\begin{array}{c}\text { EI, } \\
\%\end{array}$ & $\begin{array}{c}\text { II, ЯГП, } \\
\text { M } \pm \text { m } \\
(\min -\max )\end{array}$ \\
\hline Спеціалізовані гусегосподарства & $600-4200$ & 420 & 68 & 16,19 & $\begin{array}{c}70,35 \pm 15,18 \\
(20 \pm 240)\end{array}$ \\
Особисті селянські та фермерські & $10-150$ & 1851 & 453 & 24,47 & $\begin{array}{r}97,78 \pm 10,75 \\
(20 \pm 300)\end{array}$ \\
\hline
\end{tabular}

В особистих селянських та фермерських господарствах екстенсивність і інтенсивність інвазії гусей $\epsilon$ вищою $(24,47 \%$ та 97,78 $\pm 10,75$ ЯГП), ніж у спеціалізованих гусегосподарствах $(16,19 \%$ та $70,35 \pm$ 15,18 ЯГП).

Таблиця 3

Форми перебігу трихостронгільозу в гусей
Встановлено, що трихостронгільоз гусей частіше перебігає у складі мікстінвазій травного каналу птиці разом з протозоозами та нематодозами (табл. 3).

\begin{tabular}{lccc}
\hline \multicolumn{1}{c}{ Види інвазії } & $\begin{array}{c}\text { Інвазовано } \\
\text { (гол.) }\end{array}$ & $\begin{array}{c}\text { EI, \% } \\
(\mathrm{n}=2271)\end{array}$ & $\begin{array}{c}\text { \% від інвазованої птиці } \\
(\mathrm{n}=521)\end{array}$ \\
\hline Моноінвазія & 110 & 4,84 & 21,11 \\
Мікстінвазії & 411 & 18,09 & 78,89 \\
\hline
\end{tabular}


Так екстенсивність мікстінвазій сягала 18,09\%, що становить 78,9\% від загальної кількості хворих на трихостронгільоз гусей. Водночас, екстенсивність трихостронгільозної моноінвазії становить лише 4,84 \% (21,11\% від загальної кількості інвазованої T. tenuis птиці).

Отже, отримані результати проведених досліджень свідчать про значне поширення трихостронгільозу серед популяції домашніх гусей на території Полтавської області. Причому показники інвазованості залежать від потужності господарства, де найбільш уражаються гуси, що утримуються в особистих селянських та фермерських господарствах. На нашу думку, це пов'язане 3 недотриманням ветеринарносанітарних заходів у таких господарствах порівняно зі спеціалізованими гусегосподарствами. Отримані нами дані підтверджують результати досліджень, згідно яких, в особистих селянських господарствах екстенсивність інвазії гусей T. tenuis була вищою (ЕI $14,98 \%$, , ніж у спеціалізованих господарствах (1,18\%) (Myhajljutenko, 2013).

Також виявлено, що трихостронгільоз гусей частіше перебігає у складі мікстінвазій травного з протозоозами та нематодозами травного каналу. Такі дані підтверджують окремі автори, що вказують на асоційований перебіг у гусей T. tenuis 3 капіляріями, амідостомами, гетеракісами та дрепанідотеніями (Yevstafieva \& Yeresko, 2018).

\section{Висновки}

Копроовоскопічними дослідженнями домашніх гусей (Anser anser dom.) встановлено значне поширення трихостронгільозу на території Полтавської області, де середня екстенсивність та інтенсивність інвазії становили 22,94\% та 89,79 \pm 8,22 яєць у 1 г посліду. Водночас, в особистих селянських та фермерських господарствах показники ураженості гусей Trichostrongylus tenuis є вищими, ніж у спеціалізованих гусегосподарствах. Виявлено, що трихостронгільоз частіше перебігає у складі асоційовних інвазій гусей $(78,89$ \% від загальної кількості інвазованих гусей).

Перспективи подальших досліджень. Проведені дослідження обумовлюють необхідність вивчення питань щодо епізоотологічних особливостей трихостронгільозу гусей з урахуванням сезонної та вікової динаміки інвазії, а також ефективності лікувальнопрофілактичних заходів.

\section{References}

Bhat, S. A., Khajuria, J. K., Katoch, R., Wani, M. Y., \& Dhama, K. (2014). Prevalence of endoparasites in backyard poultry in North Indian Region: a performance based assessment study. Asian Journal of Animal and Veterinary Advances, 9, 479-488. doi: 10.3923/ajava.2014.479.488.

Boz, M. A., Sarica, M., \& Yamak, U. S. (2017). Production traits of artificially and naturally hatched geese in intensive and free-range systems: I. Growth traits. British Poultry Science, 58(2), 132-138. doi: 10.1080/00071668.2016.1261997.

Delahay, R., \& Moss, R. (1996). Food intake, weight changes and egg production in captive red grouse before and during laying: Effects of the parasitic nematode Trichostrongylus tenuis. Condor, 98(3), 501-511. doi: 10.2307/1369564.

Elmberg, J., Berg, C., Lerner, H., Waldenström, J., \& Hessel, R. (2017). Potential disease transmission from wild geese and swans to livestock, poultry and humans: a review of the scientific literature from a One Health perspective. Infection Ecology \& Epidemiology, 7(1), 1300450. doi: 10.1080/20008686.

Enigk, K., \& Dey-Hazra, A. (1971). Propagation and treatment of the Trichostrongylus tenuis infestations. Berliner und Münchener Tierärztliche Wochenschrift, 84(1), 11-14. https://www.ncbi.nlm.nih.gov/pubmed/ 5099764 .

Hamadani, H., Khan, A. A., Wani, Z. A., Jalal, H., Bihaqi, S. J. A., \& Mir, M. S. (2017). Parasitic profile of domestic geese of Kashmir. International Journal of Livestock Research, 7(5), 129-133. doi: 10.5455/ijlr.20170409094535.

Hudson, P. J., Dobson, A. P., \& Newborn, D. (1992). Do parasites make prey vulnerable to predation? Red grouse and parasites. Journal of Animal Ecology, 61, 681-692. doi: 10.2307/5623.

Katerynych, O. O., Gadjuchko, O. T., \& Hvostyk, V. P. (2006). Vitchyznjane gusivnyctvo ta svitovi tendencii' rozvytku. Ptahivnyctvo, 58, 87-90 (in Ukrainian).

Konell, A. L., Sato, A. P., Stival, M., Malaguini, N. P., Anjos, A. D., Ferreira, R. F., \& Locatelli-Dittrich, R. (2019). Serosurvey of Toxoplasma gondii, Sarcocystis sp. and Neospora caninum in geese (Anser sp.) from urban parks and captivity. Revista Brasileira de Parasitologia Veterinária, 28(2), 221-228. doi: 10.1590/S1984-29612019042.

Kornaś, S., Basiaga, M., Kowal, J., Nosal, P., Wierzbowska, I., \& Kapkowska, E. (2015). Zatorska goose a subject of parasitological research. Annals of Parasitology, 61(4), 253-256. doi: 10.17420/ap6104.15.

Marshalkina, T. V., Zaikina, G. V., \& Jevtushenko, A. V. (2012). Poshyrennja gel'mintoziv ta protozooziv sil's'kogospodars'koi' ptyci regionu Dnipropetrovshhyny. Veterynarna Medycyna, 96, 308-309 (in Ukrainian).

Myhajljutenko, S. M. (2013). Epizootychna sytuacija shhodo gel'mintoziv gusej v gospodarstvah Poltavs'kij oblasti. Bulletin of Poltava State Agrarian Academy, 1, 183-185 (in Ukrainian).

Newborn, D., \& Foster, R. (2002). Control of parasite burdens in wild red grouse Lagopus lagopus scoticus through the indirect application of anthelmintics. Journal of Applied Ecology, 39, 909-914. doi: 10.1046/j.1365-2664.2002.00771.x.

Romanov, M. N. (1999). Goose production efficiency as influenced by genotype, nutrition and production systems. World's Poultry Science Journal, 55(3), 281294. doi: 10.1079/WPS19990021. 
Ruban, N. O., Orishhuk, O. S., Cap, S. V., \& Darmograj, L. M. (2016). Zabijni pokaznyky i m'jasni jakosti molodnjaku gusej za riznogo vmistu lecytynu sonjashnyku v kombikormi. Scientific Messenger of LNU of Veterinary Medicine and Biotechnologies. Series: Veterinary Sciences, 18(2), 230-234 (in Ukrainian).

Seivwright, L. J., Redpath, S. M., Mougeot, F., Watt, L., \& Hudson, P. J. (2004). Faecal egg counts provide a reliable measure of Trichostrongylus tenuis intensities in free-living red grouse Lagopus lagpus scoticus. Journal of Helminthology, 78, 69-76. doi: $10.1079 /$ joh2003220.

Shaw, J. L., \& Moss, R. (1989). The role of parasite fecundity and longevity in the success of Trichostrongylus tenuis in low density red grouse populations. Parasitology, 99(2), 253-258. doi: $10.1017 / \mathrm{s} 0031182000058704$.
Shutler, D., Alisauskas, R. T., \& McLaughlin, D. J. (2012). Associations between body composition and helminths of lesser snow geese during winter and spring migration. International Journal for Parasitology, 42(8), 755-760. doi: 10.1016/j.ijpara.2012.05.008.

Trach, V. N. (1992). Rekomendacii po primeneniju novogo metoda ucheta jaic gel'mintov i cist prostejshih $\mathrm{v}$ fekalijah zhivotnyh. Gosagroprom USSR, Kiev (in Russian).

Webster, L. M. I., Johnson, P. C. D., Adam, A., Mable, B. K., \& Keller, L. F. (2007). Macrogeographic populations structure in a parasitic nematode with avian hosts. Veterinary Parasitology, 144, 93-103. doi: 10.1016/j.vetpar.2006.09.027.

Yevstafieva, V. O., Yeresko, V. I. (2018). Asociatyvnyj perebig kapiljariozu gusej na terytorii' Poltavs'koi' oblasti. Scientific Messenger of LNU of Veterinary Medicine and Biotechnologies. Series: Veterinary Sciences, 20(83), 73-76 (in Ukrainian). 